\title{
Implikasi Hukum Terkait Dengan Pelaksanaan Pasal 24 Undang-Undang Nomor 41 Tahun 2004 Tentang Wakaf
}

\author{
Sabri Fataruba \\ Fakultas Hukum Universitas Pattimura, Ambon, Indonesia \\ E-mail: sabrifataruba@gmail.com
}

\begin{abstract}
Article 24 of Law Number 41 Year 2004 on Wakaf states that wakaf with testament both orally and in writing can only be done if witnessed by at least 2 (two) witnesses who meet the requirements. The statement that wakaf with a will, either orally or in writing can only be done if witnessed by at least 2 (two) witnesses fulfilling the requirements as meant in Article 24 of Law Number 41 Year 2004 above means that if the endowers with oral or written testimony is not witnessed by at least 2 (two) witnesses who fulfill the requirements, it will have a legal effect on the validity of the waqf status. However, after the following articles and / or paragraphs of Law Number 41 Year 2004 along with their explanation, as well as Government Regulation Number 42 of 2006 on Implementation of Law Number 41 Year 2004 About Wakaf, there was not found any article explains what legal implications would be if the wakaf testament is not witnessed by at least 2 (two) witnesses who meet the requirements.

Therefore, in order to overcome the incompleteness resulting in the ineffectiveness of Article 24, if there are any concrete events related to the will of judgment submitted to the court to be resolved, the judge shall be able to use the method of legal discovery, either according to the science of law or according to Islamic law appropriately, so it can provide legal certainty for justice seekers.
\end{abstract}

Keywords: Legal Implications, Implementation, Laws, Endowments.

\section{A. PENDAHULUAN.}

Dalam membicarakan masalah yang berkaitan dengan hukum, maka secara sederhana terlintas di dalam pikiran, hukum adalah peraturan peraturan atau seperangkat norma yang mengatur tingkah laku manusia dalam suatu masyarakat, baik peraturan atau norma itu berupa kenyataan yang tumbuh dan berkembang dalam masyarakat, maupun peraturan atau norma yang dibuat dengan cara tertentu dan ditegakkan oleh penguasa. Bentuknya mungkin berupa hukum tidak tertulis seperti hukum adat, mungkin pula berupa hokum tertulis dalam Peraturan 
Perundang-undangan yang dibuat oleh negara ${ }^{1}$.

Hukum bukan saja merupakan gejala normatif, melainkan juga merupakan gejala sosial atau empiris, hal tersebut diketahui dari pengertian hukum yang dikemukakan oleh Mochtar Kusumaatmadja, yaitu Jika diartikan dalam artinya yang luas maka hukum itu tidak saja merupakan keseluruhan asas-asas dan kaidah-kaidah yang mengatur kehidupan manusia dalam masyarakat melainkan meliputi pula lembaga-lembaga dan proses-proses yang mewujudkan berlakunya kaidah-kaidah itu dalam kenyataan ${ }^{2}$. Dengan kata lain perkataan suatu pendekatan yang normatif semata-mata tentang hukum tidak cukup apabila kita hendak melakukan pembinaan hukum secara menyeluruh $^{3}$

Di Indonesia terdapat tiga (3) sistem hukum yang berlaku, yaitu Hukum Adat, Hukum Islam dan Hukum Perdata. Ke-3 (tiga) sistem hukum tersebut saling mengisi untuk diperlakukan bagi masyarakat yang berada di dalam wilayah Negara Republik Indonesia.

Hukum Adat menurut pandangan yang dikemukakan oleh Soepomo adalah suatu hukum yang hidup, karena ia menjelmakan perasaan hukum yang nyata dari rakyat, serta hukum adat bersifat dinamis dan akan tumbuh serta berkembang sejalan dengan perkembangan masyarakat ${ }^{4}$

Hukum Islam adalah hukum yang bersumber dari dan menjadi bagian agama Islam. Sebagai sistem hukum ia mempunyai beberapa istilah kunci, yang dimaksud adalah istilah-istilah (1) hukum,

1 M. Daud Ali, Hukum Islam, Rajawali Pers, Jakarta, 2990, h. 43

2 Mochtar Kusumatmadja, Pembinan Hukum Dalam Rangka Pembangunan Nasional, Cet.I, Bina Cipta, Bandung 1975, Hal. 11

3 Ibid

4 Soepomo, Bab-Bab Hukum Adat, Pradnya Paramita, Jakarta, 1983, h. 7
(2) hukm dan ahkam, (3) syariah atau syariat, (4) fiqih atau fiqh ${ }^{5}$.

Sedangkan Hukum Perdata dalam arti yang luas meliputi semua hukum "privat materiil" yaitu segala hukum pokok yang mengatur kepentingan kepentingan perseorangan ${ }^{6}$.

Dalam kaitannya dengan hukum Islam, salah satu bagian dari Hukum Islam adalah wakaf. Wakaf adalah suatu lembaga hukum Islam yang terdapat di berbagai daerah-daerah di Indonesia telah diterima oleh masyarakat. Wakaf dalam masyarakat tidaklah mengherankan, karena sebagian besar masyarakat Indonesia beragama Islam.

Secara etimologi kata wakaf berasal dari bahasa Arab, waqf yang berarti habs yaitu menghentikan atau menahan. Menurut Ahli fiqih, waqf artinya menahan yang mungkin diambil manfaatnya tanpa menghabisakan atau merusakkan bendanya dan dipergunakan untuk kebaikan. Menurut Imam Syafi'i, wakaf adalah suatu ibadah yang disyariatkan, wakaf telah berlaku sah bilamana wakif telah menyatakan dengan perkataan waqaftu (telah saya wakafkan), sekalipun tanpa diputuskan hakim ${ }^{7}$. Al-Jazairi menambahkan pengertian menahan dalam terminologi wakaf itu berarti barang wakaf itu tidak boleh diwariskan, tidak boleh dijual dan tidak boleh dihibahkan ${ }^{8}$.

Wakaf, sebagaimana dijelaskan oleh beberapa ulama seperti Imam Syafi'i dan Al-Jazairi, baik klasik maupun kontemporer, tidak hanya memiliki nilai ibadah semata, melainkan juga memiliki nilai sosial-ekonomi yang cukup besar. Dua posisi dan peran wakaf tersebut

\footnotetext{
5 M. Daud Ali, Op Cit, h. 42

6 Subekti, Pokok-Pokok Hukum Perdata, Cetakan XXIV, PT Intermasa, 1992 h . 9

7 Abdul Ghofur Anshori, Hukum dan Praktik Perwakafan di Indonesia, Yogyakarta Pilar Media, 2006, h. 33

7 Ibid

8 Direktorat Pemberdayaan Wakaf, Pemberdayaan Wakaf Produktif. Jakarta 2012, h. 1
}

20 |S A S I Volume 24 No. 1, Januari - Juni 2018 
(ibadah dan sosial ekonomi) telah menjadi bagian dari kehidupan umat Islam sejak lama, khususnya pada masa-masa awal perkembangan agama Islam itu sendiri ${ }^{9}$.

Peraturan Pemerintah Nomor 28 Tahun 1977 dan Kompilasi Hukum Islam (KHI), menyebutkan bahwa wakaf adalah perbuatan hukum seseorang atau sekelompok orang atau badan hukum yang memisahkan sebagian benda dari miliknya dan melembagakan untuk selama-lamanya guna kepentingan ibadat atau keperluan lainnya sesuai dengan ajaran Islam.

Secara yuridis wakaf merupakan perbuatan hukum yang menimbulkan atau mengakibatkan adanya harta yang terpisah dan bertujuan serta adanya nazhir yang mengelola harta tersebut. ${ }^{10}$ Sementara pengertian wakaf menurut Undang-undang Nomor. 41 Tahun 2004 Tentang Wakaf dijelaskan bahwa wakaf adalah perbuatan hukum wakif untuk memisahkan dan/atau menyerahkan sebagian harta benda miliknya untuk dimanfaatkan selamanya atau untuk jangka waktu tertentu sesuai dengan kepentingannya guna keperluan ibadah dan/atau kesejahteraan umum menurut syariah.

Banyak keutamaan wakaf diisyaratkan dalam dasar-dasar hukum wakaf, baik yang terdapat dalam Al-Quran maupun As-Sunnah, diantaranya dapat dirumuskan sebagai berikut ${ }^{11}$ :

1) Wakaf menanamkan sifat zuhud dan memberikan pertolongan untuk kepentingan orang lain;

2) Menghidupkan lembaga-lembaga sosial maupun keagamaan demi syi'ar Islam dan keunggulan kaum Muslimin;

\section{Ibid}

10 Taufiq, Ultimatum, Vol. 1 No. 4 2003, h, $8-9$

11 Ahmad Rofiq, Hukum Perdata Islam di Indonesia, Raja Grafindo Persada, Jakarta, 2013, h,. 390-391
3) Menanamkan kesadaran bahwa di dalam setiap harta benda, meski telah menjadi milik sah, mempunyai fungsi sosial;

4) Wakaf menyadarkan 'seseorang bahwa kehidupan di akhirat memerlukan persiapan yang cukup, wakaf adalah tindakan hukum yang menjanjikan pahala yang berkesinambungan.

Sedangkan menurut Pasal 4 dan 5 Undang-undang Nomor 41 Tahun 2004 menyebutkan tujuan dan fungsi wakaf yaitu memanfaatkan harta benda wakaf sesuai dengan fungsinya, yaitu mewujudkan potensi dan manfaat ekonomis harta benda wakaf untuk kepentingan ibadah dan untuk memajukan kesejahteraan umum.

Wakaf dilaksanakan dengan memenuhi unsur wakaf sebagai berikut :

1) Wakif, yaitu pihak yang mewakafkan harta benda miliknya;

2) Nazhir, yaitu pihak yang menerima harta benda wakaf dari wakif untuk dikelola

3) Harta benda wakaf, yaitu harta benda yang memiliki daya tahan lama dan/atau manfaat jangka panjang serta mempunyai nilai ekonomi menurut syari'ah yang diwakafkan oleh wakif.

4) Peruntukan harta benda wakaf, yaitu bagi :

a) Sarana dan kegiatan ibadah;

b) Sarana dan kegiatan pendidikan serta kesehatan ;

c) Bantuan kepada fakir miskin, anak terlantar, yatim piatu, beasiswa;

d) Kemajuan dan peningkatan ekonomi umat dan/atau;

e) Kemajuan kesejahteraan umum lainnya yang tidak bertentangan dengan syariah dan peraturan perundang-undangan.

5) Jangka waktu wakaf. Untuk jangka waktu wakaf tidak diatur secara tegas dalam Undang-undang Nomor 
41 Tahun 2004, namun demikian, jika dicermati ketentuan dalam Pasal 1 angka 1 dapatlah disimpulkan bahwa jangka waktu wakaf adalah selamanya dan untuk jangka wkatu tertentu.

Wakaf, selain dilakukan seketika, yaitu setelah ikrar wakaf diucapkan, tetapi juga dilakukan secara wasiat. Wakaf dengan wasiat dilaksanakan oleh penerima wasiat setelah pewasiat yang bersangkutan meninggal dunia. Penerima wasiat bertindak selaku wakif, yaitu pihak yang mewakafkan harta benda miliknya.

Harta benda wakaf yang diwakafkan dengan wasiat paling banyak $1 / 3$ (satu pertiga) dari jumlah harta warisan setelah dikurangi dengan utang pewasiat, kecuali dengan persetujuan seluruh ahli waris.

Selanjutnya Pasal 24 Undang undang Nomor 41 Tahun 2004 Tentang Wakaf menyebutkan bahwa wakaf dengan wasiat baik secara lisan maupun secara tertulis hanya dapat dilakukan apabila disaksikan oleh paling sedikit 2 (dua) orang saksi yang memenuhi persyaratan.

Pernyataan bahwa wakaf dengan wasiat, baik secara lisan maupun secara tertulis hanya dapat dilakukan apabila disaksikan oleh paling sedikit 2 (dua) orang saksi yang memenuhi persyaratan sebagaimana yang dimaksudkan dalam Pasal 24 Undang-undang Nomor 41 Tahun 2004 di atas mengandung makna bahwa apabila wakaf dengan wasiat baik secara lisan maupun secara tertulis tidak disaksikan oleh paling sedikit 2 (dua) orang saksi yang memenuhi persyaratan, maka akan berdampak hukum bagi keabsahan status wakaf dimaksud.

Namun demikian, setelah ditelusuri pasal-pasal dan/atau ayat selanjutnya dari Undang-undang Nomor 41 Tahun 2004 beserta penjelasannya, maupun Peraturan Pemerintah Nomor 42 Tahun 2006 Tentang Pelaksanaan
Undang-undang Nomor 41 Tahun 2004 Tentang Wakaf, ternyata tidak ditemui satu pun pasal yang menjelaskan tentang implikasi hukum apa jika wakaf wasiat tidak disaksikan oleh paling sedikit 2 (dua) orang saksi yang memenuhi persyaratan

\section{B. PEMBAHASAN}

\section{Subyek dan Obyek Wakaf, Ikrar Wakaf Serta Harta Benda Wakaf}

\section{a. Subyek dan Obyek Wakaf}

Subyek dari wakaf itu sendiri adalah wakif, dalam Pasal 7 UU No. 41 Tahun 2004 Tentang Wakaf, wakif meliputi :

1) Perseorangan;

2) Organisasi;

3) Badan hukum.

Wakif perseorangan hanya dapat melakukan wakaf apabila memenuhi persyaratan :

1) Dewasa;

2) Berakal sehat;

3) Tidak terhalang melakukan perbuatan hukum;

4) Pemilik sah harta benda wakaf.

Wakif organisasi sebagaimana dimaksud Pasal 7 huruf $b$ hanya dapat melakukan apabila memenuhi ketentuan organisasi untuk mewakafkan harta benda wakaf milik organisasi sesuai dengan anggaran dasar organisasi yang bersangkutan.

Sedangkan Wakif badan hukum sebagaimana dimaksud Pasal 7 huruf c hanya dapat melakukan wakaf apabila memenuhi ketentuan badan hukum untuk mewakafkan harta benda wakaf milik badan hukum sesuai dengan anggaran dasar badan hukum yang bersangkutan.

Biasanya obyek hukum adalah benda atau zaak. Pengetahuan tentang benda terdapat secara luas pada Buku II KUH Perdata tentang hukum 
kebendaan ${ }^{12}$. Dengan demikian, obyek wakaf itu sendiri adalah harta benda dari wakif.

\section{b. Ikrar Wakaf}

Ikrar adalah pernyataan kehendak dari wakif untuk mewakafkan tanah benda miliknya [Pasal 215 (3) jo. Pasal 1 (3) PP. No. 28/1977]. Dalam Undang-undang No. 41 Tahun 2004 diatur dalam Pasal 17-12. Sighat atau pernyataan wakaf harus dinyatakan dengan tegas baik secara lisan maupun tulisan, menggunakan kata "aku mewakafkan" atau "aku menahan" atau kalimat semakna lainnya.

Dengan pernyataan wakif itu, maka gugurlah hak kepemilikan wakif, benda itu menjadi milik mutlak Allah yang dimanfaatkan untuk umum. Ikrar wakaf adalah tindakan hukum yang bersifat deklaratif (sepihak), untuk itu tidak diperlukan adanya penerimaan (qabul) dari orang yang menikmati manfaat wakaf tersebut. Namun demikian, demi tertib hukum dan administrasi, guna menghindari penyalahgunaan benda wakaf, pemerintah mengeluarkan peraturan perundang-undangan yang secara organik mengatur perwakafan ${ }^{13}$.

\section{c. Harta Benda Wakaf}

Ruang lingkup harta benda wakaf tidak terbatas kepada benda tidak bergerak seperti tanah dan bangunan, tetapi dapat pula mewakafkan benda bergerak baik yang berwujud maupun tidak berwujud dan benda bergerak lainnya.jenis harta benda wakaf ini selaras dengan kategori benda lazim dikonsepsikan dalam hukum perdata dan peraturan perundang-undangan lainyang terkait $^{14}$.

12 R. Soeroso, Pengantar Ilmu Hukum, Jakarta, Sinar Grafika, Jakarta 2007, h, 227

13 Ahmad Rofiq, op.cit, h, 407-408

14 Rachmadi Usman, Hukum Perwakafan Di Indonesia, Sinar Grafika, Jakarta 2000, h, 127
Sifat wakaf adalah menahan suatu benda dan memanfaatkan hasilnya, agar dapat berkesinambungan manfaat benda tersebut. Karena itu benda wakaf haruslah bertahan lama, dan tidak cepat rusak. Namun demikian wakaf tidak terbatas pada benda-benda yang tidak bergerak saja, akan tetapi dapat berupa benda bergerak. Dengan demikian dapat ditegaskan, bahwa harta benda wakaf adalah :

a) Benda tidak bergerak, seperti tanah, sawah, dan bangunan. Benda macam inilah yang sangat dianjurkan agar diwakafkan, karena mempunyai nilai jariah yang lebih lama.

b) Benda bergerak, seperti mobil, sepeda motor, binatang ternak, atau benda-benda lainnya. Yang terakhir ini dapat juga diwakafkan. Namun demikian, inilah jariahnya terbatas hingga benda-benda tersebut dapat dipertahankan. Bagaimanapun juga, apabila benda-benda itu tidak dapat lagi dipertahankan keberadaannya, maka selesailah wakaf tersebut ${ }^{15}$.

Sementara ulama ada yang membagi benda wakaf kepada benda yang berbentuk Masjid dan bukan Masjid. Yang berbentuk masjid jelas termasuk pada benda yang tidak bergerak, untuk benda yang bukan berbentuk masjid dibagi seperti pembagian terdahulu yaitu benda tidak bergerak dan benda bergerak ${ }^{16}$.

Adapun penjelasan harta benda wakaf dalam Pasal 15-27 PP No. 42 Tahun 2006 Tentang Pelaksanaan Undang-undang Nomor. 41 Tahun 2004 Tentang Wakaf.

Pasal 15 menyebutkan jenis harta benda wakaf meliputi :

a) Benda tidak bergerak.

b) Benda bergerak selain uang.

c) Benda bergerak uang.

15 Ahmad Rofiq, Hukum Islam Di Indonesia, Raja Grafindo Persada, Jakarta 2000, h, 505 16 Ibid 
Pasal 16 menyebutkan :

a) Hak atas tanah sesuai dengan ketentuan peraturan perundang undangan baik yang sudah maupun belum terdaftar.

b) Bangunan atau bagian bangunan yang berdiri di atas tanah sebagaimana dimaksud pada huruf a.

c) Tanaman dan benda lain yang berkaitan dengan tanah.

d) Hak milik atas satuan rumah susun sesuai dengan ketentuan peratruran perundang-undangan.

e) Benda tidak bergerak lain sesuai dengan ketentuan prinsip syariah dan peraturan perundang-undangan.

Pasal 19 menyebutkan :

1) Benda digolongkan sebagai benda bergerak karena sifatnya dapat berpindah atau dipindahkan atau karena ketetapan Undang-Undang.

2) Benda bergerak terbagi dalam benda bergerak yang dapat dihabiskan dan yang tidak dapat dihabiskan karena pemakaian.

3) Benda bergerak yang dapat dihabiskan karena pemakaiannya tidak dapat diwakafkan, kecuali air dan bahan bakar minyak yang persediaannya berkelanjutan.

4) Benda bergerak yang tidak dapat dihabiskan karena pemakaian dapat diwakafkan dengan memperhatikan ketentuan prinsip syariah.

\section{Kedudukan Wakaf Wasiat Dalam Undang-undang Nomor 41 Tahun 2004}

Kedudukan wakaf wasiat itu sendiri dalam Undang-Undang Nomor 41 Tahun 2004 Tentang Wakaf terdapat dalam Bab II bagian kesembilan (9) wakaf dengan wasiat Pasal 24-27, yang berbunyi :

Pasal 24 menyebutkan :
"Wakaf dengan wasiat baik secara lisan maupun secara tertulis hanya dapat dilakukan apabila disaksikan oleh paling sedikit 2 (dua) orang saksi yang memenuhi persyaratan sebagaimana dimaksud dalam Pasal 20”.

Pasal 25 menyebutkan :

"Harta benda wakaf yang diwakafkan dengan wasiat paling banyak $1 / 3$ (satu pertiga) dari jumlah harta warisan setelah dikurangi dengan utang pewasiat, kecuali dengan persetujuan seluruh ahli waris".

Pasal 26 menyebutkan :

"Wakaf dengan wasiat dilaksanakan oleh penerima wasiat setelah pewasiat yang bersangkutan meninggal dunia”.

Penerima wasiat sebagaimana dimaksud pada ayat (1) bertindak sebagai kuasa wakif. Wakaf dengan wasiat sebagaimana dimaksud pada ayat (1) dan ayat (2) dilaksanakan sesuai dengan tata cara perwakafan yang diatur dalam undang-undang ini.

Pasal 27 menyebutkan :

"Dalam hal wakaf dengan wasiat tidak dilaksanakan oleh penerima wasiat, atas permintaan pihak yang berkepentingan, pengadilan dapat memerintahkan penerima wasiat yang bersangkutan untuk melaksanakan wasiat".

\section{Mekanisme Wakaf Dengan Wasiat}

Sesuai dengan pernyataan pada Pasal 26 ayat (3) Undang-Undang Nomor 41 Tahun 2004 Tentang wakaf bahwa wakaf wasiat dilaksanakan sesuai dengan tata cara perwakafan yang diatur dalam Undang-undang. Dengan demikian, mekanisme wakaf dengan wasiat tidaklah 
berbeda dengan tata cara wakaf pada umumnya.

Dalam Kompilasi Hukum Islam Pasal 223 dinyatakan sebagai berikut :

1) Pihak yang hendak mewakafkan dapat menyetakan ikrar wakaf di hadapan pejabat pembuat akta ikrar wakaf untuk melaksanakan ikrar wakaf.

2) Isi dan bentuk ikrar wakaf ditetapkan oleh Menteri Agama.

3) Pelaksanaan ikrar, demikian pula pembuatan akta ikrar wakaf, dianggap sah jika dihadiri dan disaksikan oleh sekurang-kurangnya 2 (dua) orang saksi.

4) Dalam melaksanakan ikrar seperti dimaksud ayat (1) pihak yang mewakafkan diharuskan menyerahkan kepada pejabat yang tersebut

Dalam Pasal 215 ayat (6) surat-surat sebagai berikut :

1) Tanda bukti pemilikan harta benda;

2) Jika benda yang diwakafkan berupa benda tidak bergerak maka harus disertai surat keterangan dari kepala desa, yang diperkuat oleh camat setempat yang menerangkan pemilikan benda tidak bergerak dimaksud.

3) Surat atau dokumen tertulis yang merupakan kelengkapan dari benda tidak bergerak yang bersangkutan.

Dalam Pasal 9 PP No. 28 Tahun 1977, dalam Pasal tersebut ada tambahan, yaitu pada huruf d. izin dari Bupati/Walikotamadya Kepala Daerah cq. Kepala Sub Direktorat Agraria sekarang Kepala Badan Pertanahan setempat.

Dalam Pasal 10 PP No. 28 Tahun 1977 ditambahkan beberapa ayat sebagai berikut:

1) Bupati/Walikotamadya Kepala Daerah cq. Kepala Sub Direktorat Agraria setempat, setelah menerima pemohonan tersebut dalam ayat (1) mencatat perwakafan tanah milik yang bersangkutan pada buku tanah dan sertifikatnya.

2) Jika tanah milik yang diwakafkan belum mempunyai serifikat, maka pencatatan yang dimaksudkan dalam ayat (2) dilakukan setelah untuk tanah tersebut dibuatkan sertifikatnya.

3) Oleh Menteri Dalam Negeri diatur tata cara pencatatan perwakafan yang dimaksudkan dalam ayat (2) dan (3).

4) Setelah dilakukan pencatatan perwakafan tanah milik dalam buku tanah dan sertifikatnya seperti yang dimaksudkan dalam ayat (2) dan (3), maka nadzir yang bersangkutan wajib melaporkannya kepada pejabat yang ditunjuk oleh Menteri Agama.

Tambahan dalam Pasal 10 PP di atas adalah sebagai konsekuensi PP ini dikeluarkan yang tujuannya untuk mengatur perwakafan tanah milik. Tata cara pembuatan akta ikrar wakaf benda tidak bergerak sebagaiman yang dimaksud dalam Pasal 16 dan Pasal 17 dan benda bergerak selain uang sebagaimana dimaksud dalam Pasal 19, Pasal 20, dan Pasal 21 dilaksanakan sebagai berikut :

a) Sesuai dengan peraturan perundang-undangan.

b) PPAIW meneliti kelengkapan persyaratan administrasi perwakafan dan keadaan fisik benda wakaf.

c) Dalam hal ketentuan sebagaimana dimaksud pada huruf $b$ terpenuhi, maka pelaksanaan ikrar wakaf dan pembuatan Akta Ikrar Wakaf (AIW) dianggap sah apabila dilakukan dalam Majelis Ikrar Wakaf sebagaimana yang dimaksud dalam Pasal 30 ayat (1).

d) AIW yang telah ditandatangani oleh wakif, Nadzir, 2 (dua) orang saksi, 
dan/atau mauquf'alaih disahkan oleh PPAIW.

e) Salinan AIW disampaikan kepada :

1) Wakif.

2) Nadzir.

3) Mauquf'alaih

4) Kantor pertanahan kabupaten/kota dalam hal benda wakaf berupa tanah.

5) Instansi berwenang lainnya dalam hal benda wakaf berupa benda tidak bergerak selain tanah atau benda bergerak selain uang.

Selanjutnya, apabila wakaf terjadi dan belum dibuatkan AIW, maka dibuatkan Akta Pengganti Ikrar Wakaf (APAIW) sebagaiman diatur dalam Pasal 35 sebagai berikut :

1) Tata cara pembuatan APAIW sebagaimana dimaksud dalam Pasal 31 dilaksanakan berdasarkan permohonan masyarakat atau saksi yang mengetahui keberadaan banda wakaf.

2) Permohonan masyarakat atau 2 (dua) orang saksi yang mengetahui dan mendengar perbuatan wakaf sebagaimana dimaksud pada ayat (1) harus dikuatkan dengan adanya petunjuk qarinah tentang keberadaan benda wakaf.

3) Apabila tidak ada orang yang memohon pembuatan APAIW, maka kepala desa tempat benda wakaf tersebut berada wajib meminta pembuatan APAIW tersebut kepada PPAIW setempat.

4) PPAIW atas nama Nadzir wajib menyampaikan APAIW beserta dokumen pelengkap lainnya kepada kepala kantor pertanahan kabupaten/kota setempat dalam rangka pendaftaran wakaf tanah yang bersangkuatan dalam jangka waktu paling lama 30 (tiga puluh) hari sejak penandatanganan APAIW.
Penyerahan harta benda wakaf, demi upaya tertib hukum, harus dilengkapi dengan berita acara. Apalagi harta benda wakaf, sudah menjadi milik public atau milik Allah ${ }^{17}$. Pasal 36 menegaskan :

1) Harta benda wakaf wajib diserhkan oleh wakif kepada Nadhir dengan membuat berita acara serah terima paling lambat pada saat penandatanganan AIW yang diselenggarakan dalam majelis ikrar wakaf sebagaimana dimaksud dalam Pasal 30 ayat (1).

2) Dalam berita acara serah terima sebagaimana dimaksud pada ayat (1) harus disebutkan tentang keadaan serta rincian harta benda wakaf yang ditandatangani oleh wakif dan Nadhir.

3) Berita acara serah terima sebagaiman dimaksud pada ayat (1) tidak diperlukan dalam hal serah terima benda wakaf telah dinyatakan dalam AIW.

Adapun Pejabat Pembuat Akta Ikrar Wakaf (PPAIW) benda tidak bergerak berupa tanah dan benda bergerak selain uang adalah kepala KUA dan/atau pejabat yang menyelenggarakan urusan wakaf. Dan benda bergerak berupa uang, PPAIW adalah pejabat lembaga keuangan syariah paling rendah tingkat setingkat kepala seksi LKS yang ditunjuk Menteri ${ }^{18}$.

Secara rinci diatur dalam Pasal 37 sebagai berikut :

1) PPAIW harta benda wakaf tidak bergerak selain uang adalah pejabat kepala KUA dan/atau pejabat yang menyelenggarakan urusan wakaf.

2) PPAIW harta benda wakaf bergerak selain uang, adalah kepal KUA dan/atau pejabat lain yang ditunjuk oleh Menteri.

3) PPAIW harta benda wakaf bergerak berupa uang adalah pejabat lembaga keuangan syariah paling

\footnotetext{
17 Ahmad Rofiq, Op.Cit, h, 425

18 Ibid
} 
rendah setingkat kepala seksi LKS yang ditunjuk Menteri.

4) Ketentuan sebagaimana dimaksud pada ayat (1), ayat (2), dan ayat (3) tidak menutup kesempatan bagi wakif untuk membuat AIW di hadapan Notaris.

5) Persyaratan Notaris sebagai PPAIW ditetapkan oleh Menteri.

\section{Implikasi Hukum Dalam Pelaksanaan Pasal 24 Undang - Undang Nomor 41 Tahun 2004 Tentang Wakaf}

Hukum berfungsi sebagai perlindungan kepentingan manusia. Agar kepentingan manusia terlindungi, hukum harus dilaksanakan. Pelaksanaan hukum dapat berlangsung secara normal, tetapi dapat terjadi juga karena pelanggaran hukum. Dalam hal ini hukum yang telah dilanggar itu harus ditegakkan, dan pada dasarnya tidak boleh disimpangi, fiat justicia et pereat mundus (hukum harus ditegakkan meskipun langit akan runtuh). Itulah yang diinginkan dalam rangka kepastian hukum.

Hukum harus dilaksanakan dan ditegakkan. Setiap orang mengharapkan dapat diterapkannya hukum dalam hal terjadinya peristiwa konkrit. Bagaiman hukumnya, itulah yang harus berlaku. Masyarakat mengharapkan manfaat dalam pelaksanaan atau penegakan hukum

Hukum adalah untuk manusia (masyarakat), maka pelaksanaan atau penegakan hukum harus memberi manfaat atau kegunaan bagi masyarakat. Jangan sampai, justru karena hukumnya dilaksanakan atau ditegakan timbul keresahan di masyarakat. Untuk itu, maka hukum juga harus memberi kepastian. Tanpa kepastian hukum orang tidak tahu apa yang harus diperbuatnya, dan akhirnya timbul keresahan pula ${ }^{19}$.

19 Sudikno Mertokusumo, Mengenal Hukum (Suatu Pengantar), Liberty, Yogyakarta, Edisi Ketiga, 1991, h, 134 - 135,
Undang-undang tidak sempurna. Memang tidak mungkin undang-undang itu mengatur segala kegiatan kehidupan manusia secara tuntas. Adakalanya undang-undang itu tidak lengkap dan adakalanya undang-undang itu tidak jelas $^{20}$.

Hal inilah yang terjadi pada saat diundangkannya Undang-Undang Nomor 41 Tahun 2004 Tentang Wakaf, dimana dalam Pasal 24 nya menyebutkan bahwa wakaf dengan wasiat baik secara lisan maupun secara tertulis hanya dapat dilakukan apabila disaksikan oleh paling sedikit 2 (dua) orang saksi yang memenuhi persyaratan.

Pernyataan bahwa wakaf dengan wasiat, baik secara lisan maupun secara tertulis hanya dapat dilakukan apabila disaksikan oleh paling sedikit 2 (dua) orang saksi yang memenuhi persyaratan sebagaimana yang dimaksudkan dalam Pasal 24 Undang-undang Nomor 41 Tahun 2004 tersebut mengandung makna bahwa apabila wakaf dengan wasiat baik secara lisan maupun secara tertulis tidak disaksikan oleh paling sedikit 2 (dua) orang saksi yang memenuhi persyaratan, maka akan berdampak hukum bagi keabsahan status wakaf dimaksud.

Namun demikian, setelah ditelusuri pasal-pasal dan/atau ayat selanjutnya dari Undang-undang Nomor 41 Tahun 2004 beserta penjelasannya, maupun Peraturan Pemerintah Nomor 42 Tahun 2006 Tentang Pelaksanaan Undang-undang Nomor 41 Tahun 2004 Tentang Wakaf, ternyata tidak ditemui satu pun pasal atau ayat yang menjelaskan tentang dampak atau akibat hukum bagi keabsahan status wakaf wasiat apabila tidak disaksikan oleh paling sedikit 2 (dua) orang saksi yang memenuhi persyaratan.

Dengan demikian, Undang Undang Nomor 41 Tahun 2004, khususnya Pasal 24 adalah tidak jelas dan/atau tidak lengkap, yang berakibat tidak efektif, sehingga sangat sulit 
penanganannya apabila terjadi peristiwa konkrit yang harus diselesaikan oleh hakim melalui proses di pengadilan. Hakim selalu dituntut untuk dapat menyelesaikan peristiwa konkrit (perkara) yang diajukan kepadanya, sebab hakim dilarang untuk menolak suatu perkara yang diajukan kepadanya dengan alasan hukumnya tidak jelas atau tidak lengkap.

Dalam menangani masalah yang berkaitan dengan wakaf dengan wasiat ini, meskipun pemberlakuan Pasal 24 Undang-undang Nomor 41 Tahun 2004 tidak jelas atau tidak lengkap, tetapi apabila ada peristiwa konkrit (perkara) yang bermuara ke pengadilan, hakim dituntut untuk dapat menyelesaikannya dengan cara mencari dan menemukan hukumnya.

Untuk dapat mencari dan menemukan hukum itu, hakim perlu melakukan penafsiran yang dalam ilmu hukum dikenal beberapa metode, yaitu : penafsiran tata bahasa (gramatikal), penafsiran sahih (autentik/resmi), penafsiran historis, penafsiran sistematis, penafsiran nasional, penafsiran teleologis/sosiologis, penafsiran ekstensif (luas), penafsiran restriktif, penafsiran analogis, serta penafsiran a contrario.

Selain ilmu hukum, untuk mencari dan menemukan hukum apabila terjadi peristiwa kongkrit yang berkaitan dengan masalah wakaf dengan wasiat ini, maka penting bagi hakim pula untuk mempertimbangkan sumber hukum Islam yang ketiga, yaitu ijtihad yang dilakukan dengan menggunakan akal (ar-ra'yu). Penggunaan akal untuk berijtihad telah dibenarkan oleh Nabi Muhammad SAW seperti yang terdapat dalam Hadits Mu'az bin Jabal, bahkan terdapat ketentuannya pula dalam Surat an-Nisa (4) ayat 59. Ijtihad adalah suatu usaha atau ikhtiar yang sungguh dengan menggunakan segenap kemampuan yang ada, dilakukan oleh orang (ahli hukum) yang memenuhi syarat untuk merumuskan garis hukum yang belum jelas atau tidak ada ketentuannya di dalam Al-Qur'an dan
Sunnah Rasulullah. ${ }^{21}$

Adapun metode atau cara berijtihad tersebut, yaitu :

1) Ijmak, yaitu persetujuan atau kesesuaian pendapat para ahli mengenai sesuatu masalah pada suatu tempat di suatu masa;

2) Qiyas, yaitu menyamakan hukum suatu hal yang tidak terdapat ketentuannya dalam Al-Qur'an dan as-Sunnah Rasul yang terdapat dalam Kitab-kitab Hadis karena persamaan Illat (penyebab atau alasannya);

3) Istidal, yaitu menarik kesimpulan dari hal-hal yang berlainan. Misalnya menarik kesimpulan dari adat-istiadat dan hukum agama yang diwahyukan sebelum Islam;

4) Al-Musalih - al-Mursalah, yaitu cara menemukan hukum sesuatu hal yang tidak terdapat ketentuannya, baik dalam Al-Qur'an maupun dalam Kitab - kitab Hadis, berdasarkan pertimbangan kemaslahatan masyarakat atau kepentingan umum.;

5) Istishan, yaitu cara menemukan hukum dengan menyimpang dari ketentuan yang sudah ada demi keadilan dan kepentingan sosial;

6) Istishab, yaitu menetapkan hukum sesuatu hal menurut keadaan yang terjadi sebelumnya. Atau dengan perkataan lain dapat dikatakan Istishab adalah melangsungkan berlakunya hukum yang telah ada karena belum ada ketentuan lain yang membatalkannya;

7) Adat-istiadat (urf), yaitu adat-istiadat yang tidak bertentangan dengan hukum Islam dapat dikukuhkan terus berlaku bagi masyarakat yang bersangkutan ${ }^{22}$.

21 Muhammad Daud Ali, Hukum Islam; Pengantar Ilmu Hukum dan Tata Hukum Islam di Indonesia, RajaGrafindo Persada, Jakarta, Cetakan 8, 2000, h, 106

22 Ibid, h, $108-111$ 
Metode-metode penemuan hukum, baik menurut ilmu hukum maupun menurut hukum Islam sebagaimana dikemukakan di atas harus dapat dimanfaatkan oleh hakim secara tepat dalam menutupi ketidaklengkapan Undang-undang Nomor 41 Tahun 2004, apabila ada peristiwa konkrit yang berkaitan dengan wakaf wasiat yang diajukan untuk diselesaikan di pengadilan, sehingga dengan demikian dapat memberikan kepastian hukum bagi pencari keadilan, meskipun Undang-Undang Nomor 41 Tahun 2004 itu sendiri tidak lengkap.

\section{PE N U T P}

Setelah uraian pembahasan di atas, akhirnya penulis dapat menyimpulkan bahwa Undang-undang Nomor 41 Tahun 2004 Tentang Wakaf, khususnya Pasal 24 adalah tidak lengkap, bahkan dapat dikatakan tidak efektif.. Dengan demikian, untuk mengatasi ketidaklengkapan yang berakibat pada ketidakefektifan dalam Pasal 24 dimaksud, maka apabila ada peristiwa kongkrit yang berkaitan dengan wakaf wasiat yang diajukan ke pengadilan untuk diselesaikan, hakim harus dapat menggunakan metode penemuan hukum, baik menurut ilmu hukum maupun menurut hukum Islam secara tepat, sehingga dapat memberikan kepastian hukum bagi pencari keadilan.

\section{DAFTAR PUSTAKA}

Abdul Ghofur Anshori, Hukum dan Praktik Perwakafan di Indonesia, Yogyakarta Pilar Media, 2006

Ahmad Rofiq, Hukum Perdata Islam di Indonesia, PT. Raja Grafindo Persada, Jakarta, 2013

Direktorat Pemberdayaan Wakaf , Pemberdayaan Wakaf Produktif. Jakarta 2012

Mochtar Kusumaatmadja, Pembinan
Hukum Dalam Rangka

Pembangunan Nasional, Cet.I, Bina

Cipta, Bandung 1975

Muhammad Daud Ali, Hukum Islam, Rajawali Pers, Jakarta, 1990

Islam.

Pengantar Ilmu Hukum dan Tata

Hukum Islam di Indonesia,

RajaGrafindo Persada, Jakarta, Cetakan 8, 2000

Rachmadi Usman, Hukum Perwakafan Di Indonesia, Sinar Grafika, Jakarta 2000

R. Soeroso, Pengantar Ilmu Hukum, Jakarta, Sinar Grafika, Jakarta 2007

Soepomo, Bab-Bab Hukum Adat, Pradnya Paramita, Jakarta, 1983

Subekti, Pokok-Pokok Hukum Perdata, Cetakan XXIV, PT Intermasa, 1992

Sudikno Mertokusumo, Mengenal Hukum (Suatu Pengantar), Liberty, Yogyakarta, Edisi Ketiga, 1991

Taufiq, Ultimatum, Vol. 1 No. 42003 